\title{
Detection of a nodavirus-like agent in heart tissue from reared Atlantic salmon Salmo salar suffering from cardiac myopathy syndrome (CMS)
}

\author{
Sindre Grotmol ${ }^{1, *}$, Geir K. Totland ${ }^{2}$, Harald Kryvi ${ }^{2}$ \\ ${ }^{1}$ Institute of Marine Research, Department of Aquaculture, PO Box 1870 Nordnes, N-5024 Bergen, Norway \\ ${ }^{2}$ University of Bergen, Institute of Zoology, Allégt. 41, N-5007 Bergen, Norway
}

\begin{abstract}
The present study shows that a nodavirus-like agent is associated with the lesions of cardiac myopathy syndrome (CMS), a disease of unknown etiology which affects reared adult Atlantic salmon Salmo salar. In archive paraffin-embedded heart tissue from Atlantic salmon diagnosed as suffering from CMS, a distinct immunohistochemical reaction was observed when using a primary antibody against striped jack nervous necrosis virus (Nodaviridae). Immunolabeling was detected in the mesothelium and hypercellular lesions of the epicardium and in endothelial cells and myocytes within mild multifocal lesions of the atrial and ventricular trabeculae. Transmission electron microscopy, performed on deparaffinized samples of the same tissue blocks, revealed substantial amounts of virus-like particles (VLP) in the cytoplasm of endocardial endothelium, in myocytes and in mesothelial cells of the epicardium. The VLP were isometric, spherical and unenveloped, with mean capsid diameters of approximately $25 \mathrm{~nm}$, resembling a virus belonging to the Nodaviridae.
\end{abstract}

KEY WORDS: Cardiac myopathy syndrome (CMS) - Fish $\cdot$ Atlantic salmon $\cdot$ Nodavirus $\cdot$ Immunohistochemistry

\section{INTRODUCTION}

Cardiac myopathy syndrome (CMS), also termed 'acute heart failure' or 'heart rupture', has been reported in Atlantic salmon Salmo salar from fish farms in Norway and in the Faeroe Islands, Denmark (Bruno \& Poppe 1996). The disease typically strikes large and rapidly growing fish, usually about 12 to 18 mo after transfer to seawater (Amin \& Trasti 1988, Ferguson et al. 1990). Between 1985 and 1989 the disease was diagnosed in more than 100 facilities (Ferguson et al. 1990), and has since been repeatedly reported from most fish farming areas in Norway. Little information is available on the total losses caused by the disease.

The disease is typically acute, and fish die, often in connection with feeding, without any clinical symptoms being observed. Usually, no external gross pathol-

•E-mail: sindre.grotmol@imr.no ogy is recorded. Some fish, however, show signs of chronic disease with anorexia, wasting and lethargic behavior and may develop systemic congestion with hemorrhages in the dermis and edema in the scale pockets (raised scales) (Bruno \& Poppe 1996). Exophthalmia may also be observed. Necropsy usually reveals an enlarged and often ruptured atrium and/or sinus venosus. Haemopericardium with a prominent blood coagulum is found in fish with myocardial rupture. In addition, ascites resulting from hepatic congestion, often accompanied by fibrinous perihepatic deposits, is observed (Amin \& Trasti 1988, Ferguson et al. 1990, Bruno \& Poppe 1996).

On histopathological examination, the most prominent lesions are found in the trabeculae of the heart. These comprise myocardial cell degeneration and necrosis accompanied by various degrees of endocardium-associated hypercellularity dominated by mononuclear inflammatory cells. The severity and distribution of these lesions vary between the different parts of the heart and range from mild and multi- 
focal to severe and diffuse (Amin \& Trasti 1988, Ferguson et al. 1990). In addition, epicardial mononuclear inflammatory cell infiltrations are often observed. The liver tissue is often congested, with periacinar hepatocellular degeneration and necrosis. As the etiology of CMS is unknown, the disease is diagnosed on the basis of its gross and histopathological characteristics.

The present study was initiated by the results of an immunohistochemical and electronmicroscopical study of viral encephalopathy and retinopathy (VER) in larval and juvenile Atlantic halibut Hippoglossus hippoglossus (Grotmol et al. 1997). In Atlantic halibut, lesions, probably caused by a nodavirus-like agent, were detected in endothelial cells of the endocardium. Nodavirus-like particles were also found in the myocytes and in mesothelial cells of the epicardium. It was thus tempting to determine whether a virus with similar characteristics could be identified in the heart tissue of Atlantic salmon suffering from CMS.

\section{MATERIALS AND METHODS}

The sample material used was archival paraffin embedded heart tissues from Atlantic salmon Salmo salar $\mathrm{L}$. ( $\mathrm{n}=12$ ) suffering from CMS that had been collected from fish farms ( $\mathrm{n}=4$ ) located in western Norway. The diagnosis was based on case histories and clinical signs as well as on the presence of characteristic heart and liver lesions as described by Ferguson et al. (1990). The salmon had been reared in seacages for a period of 12 to $24 \mathrm{mo}$, had been fed a commercial pelleted diet, and weighed from 2 to $8 \mathrm{~kg}$. As control material, heart tissue from 3 healthy salmon of approximately the same size was collected at a facility with no signs of clinical disease. The tissue of the control fish and the tissue from fish suffering from CMS were fixed and processed identically.

The hearts had been parted medially, put into a phosphate-buffered $10 \%$ formalin solution ( $\mathrm{pH}$ 7.4) for 12 to $48 \mathrm{~h}$, dehydrated through an ethanol series and xylene, and embedded in paraffin wax. Sections, 3 to $5 \mu \mathrm{m}$ thick, were stained with hematoxylin and eosin (H\&E) for routine histological survey.

Immunohistochemistry using a rabbit antiserum against striped jack nervous necrosis virus (antiSJNNV) was carried out according to established methods (Hsu et al. 1981, Evensen 1993). The antiserum was provided by Dr T. Nakai (University of Hiroshima, Japan) and had previously been applied in several studies on nodavirus (Munday et al. 1994, Nakai et al. 1994, Nguyen et al. 1994, 1996). The antibody was raised against purified virions of SJNNV according to procedures described previously (Ari- moto et al. 1992, Mori et al. 1992). Cross-reactions with viruses of other families have not been detected. Sections of formalin-fixed paraffin embedded heart tissue $\left(\mathrm{n}=12\right.$ ) were deparaffinized at 58 to $59^{\circ} \mathrm{C}$ for $30 \mathrm{~min}$, washed in 2 xylene baths and rehydrated through a series of decreasing concentrations of ethanol $(100 \%, 96 \%, 70 \%, 50 \%)$. Nonspecific antibody binding sites were blocked by covering the sections with a solution of $5 \%$ bovine serum albumin (BSA) in Tris-buffered saline (TBS, pH 7.4) for $20 \mathrm{~min}$. The solution was blotted off the slides and the antiSJNNV serum was incubated at a dilution of 1:900 in $2.5 \%$ BSA in TBS for $30 \mathrm{~min}$. After washing for $5 \mathrm{~min}$ in TBS, the secondary antibody, biotinylated goat anti-rabbit immunoglobulin, diluted $1: 300$ in $2.5 \%$ BSA in TBS (Dako, Glostrup, Denmark), was added and incubated for $30 \mathrm{~min}$. After washing in TBS, streptavidin alkaline phosphatase complex (diluted 1:1000; Boehringer) was added and incubated at room temperature for 30 min. After washing, New Fuchsin Chromogen (K698, Dako, Carpinteria, CA, USA) with $1 \mathrm{mM}$ levamisole (Sigma Co., St. Louis, MO, USA) as inhibitor in TBS was added and allowed to develop for $5 \mathrm{~min}$. After washing in tap water, sections were counterstained with Mayer's haematoxylin and mounted in an aqueous mounting mediun (Aquamount; BDH Laboratory Supplies, UK).

All incubations were performed at room temperature in a humidity chamber. Controls included use of nonimmune serum (normal rabbit serum) at the same dilution as the immune rabbit serum. Tissue sections from normal Atlantic salmon were also incubated with immune and nonimmune serum. The endpoint dilution value was 1:3200 (the highest dilution of the primary antibody that gives a positive reaction discernable from background) after $30 \mathrm{~min}$ incubation at room temperature (Petrusz 1983).

After a sufficient number of sections for light microscopical and immunohistochemical examinations had been collected, the paraffin blocks were deparaffinized in warm xylene $\left(58\right.$ to $\left.59^{\circ} \mathrm{C}\right)$, rehydrated through a series of decreasing concentrations of ethanol (100\%, $96 \%, 70 \%, 50 \%$ ) and refixed for $6 \mathrm{~h}$. A volume of $100 \mathrm{ml}$ refixative consisted of $10 \mathrm{ml} 10 \%$ formaldehyde, $10 \mathrm{ml} 25 \%$ glutaraldehyde, $20 \mathrm{ml} 0.2 \mathrm{M}$ cacodylate buffer and $60 \mathrm{ml}$ PBS (pH 7.35) (Totland et al. 1996). Small cubes $\left(1 \mathrm{~mm}^{3}\right)$ of tissue were dissected from the blocks in areas with immunohistochemical reaction in the paraffin sections. The selected tissue was then rinsed in the cacodylate buffer and postfixed for $2 \mathrm{~h}$ in $1 \% \mathrm{OsO}_{4}$, dehydrated in ethanol, and embedded in Epon 812 (Fluka Chemie AG, Switzerland). Ultrathin sections were cut on a LKB Ultratome, contrasted in uranyl acetate and lead citrate and observed in a Jeol CX100 transmission electron microscope. 


\section{RESULTS}

\section{Immunohistochemistry}

A specific immunolabeling was observed within characteristic cardiac lesions of diseased fish after incubation with the anti-SJNNV serum. When the nonimmune serum was applied to affected tissue and the immune serum to the heart tissue of the control fish, faint, unspecific staining could be observed in some sections. The control fish showed normal morphology of the heart tissue.

In the hearts of the fish suffering from CMS, characteristic lesions were observed both in the trabecular musculature (Fig. 1) and in the epicardium (Fig. 2). Within the epicardium, immunolabeling was present in the mesothelial lining and in the hypercellular lesions dominated by mononuclear cells (Fig. 2).

The internal cardiac lesions of the trabecular tissue varied in severity and ranged from multifocal (Fig. 1) to diffuse. Within the multifocal lesions, distinct immunolabeling was observed in the endothelial cells (Figs. 1, $3,4 \& 5$ ). Some endothelial cells were degenerate, and on some trabeculae the endothelial lining seemed to be partly lacking (Figs. $3 \& 4$ ). Margination of mononuclear cells was observed on the luminal surface of some immunolabeled endothelial cells, and different numbers of mononuclear cells were present in their subendothelial spaces (Figs. 1, 3 \& 4). Immunolabeling was observed in many of the degenerate or necrotic myocytes (Figs. $3 \& 6$ ), and was often associated with various degrees of mononuclear cell infiltration in the myocardium (Fig. 6).

In areas with diffuse severe lesions and intense inflammatory changes, the immunolabeling of the endocardium and myocardium was less pronounced or absent. The severe diffuse lesions occurred more frequently in the atrium than in the spongious part of the ventricle, and they consisted of pronounced myocardial degeneration and necrosis. Hypercellularity, mainly due to mononuclear cell infiltrations, was widespread and, in severely affected trabeculae, the myocardium had been substituted by macrophages and lymphocytes, which are signs of chronic active inflammation (Figs. $3 \& 6$ ).

The endothelium of the arterioles and venules of the compactum and the epicardium also displayed immunolabeling.

\section{Electron microscopy}

Free virus-like particles (VLP) (Fig. 7) were detected in the cytoplasm of endothelial cells, myocytes and mesothelial cells of the epicardium. The VLP were iso- metric, spherical, unenveloped and had diameters of approximately $25 \mathrm{~nm}$. The largest numbers of VLP were found in the endocardium and epicardium. In some of the degenerate myocytes, VLP were present between bundles of myofibrils. Some of the infiltrated mononuclear cells and some lymphocyte-like cells adherent to the luminal surface of the endocardium also contained VLP.

The control fish showed normal morphology with no accumulations of VLP in the cytoplasm of cells of the heart.

\section{DISCUSSION}

In the present study nodavirus-like particles and virus antigens were visualized in situ in lesions characteristic of CMS. To our knowledge this is the first report that describes the presence of a nodavirus-like agent in a salmonid. Nodaviruses pathogenic to fish are neurotropic and are the etiological agents of viral encephalopathy and retinopathy (VER), which causes high mortalities in early life stages of several cultured marine teleost species (Glazebrook et al. 1990, Yoshikoshi \& Inoue 1990, Bloch et al. 1991, Breuil et al. 1991, Mori et al. 1991, 1992, Renault et al. 1991, Munday et al. 1992, Arimoto et al. 1993, Nakai et al. 1994, Nguyen et al. 1994, Muroga 1995, Boonyaratpalin et al. 1996). In the Atlantic halibut infected with a nodavirus-like agent, early signs of endocarditis was a typical finding and nodavirus-like particles were detected in the endothelium, in myocytes and in mesothelial cells of the epicardium (Grotmol et al. 1997). The cardiac pathology of the Atlantic halibut infected with a nodavirus-like agent shared histopathological changes with Atlantic salmon suffering from CMS. This may indicate a relation between the presence of virus and the cardiac lesions.

The fact that the most distinct immunolabeling was found in the endothelial cells within mild multifocal lesions indicates that viral replication is at its peak at this early stage of disease development. The endothelium thus seems to be the primary site of viral replication in the heart. This replication probably results in endothelial degeneration and lysis, which is in accordance with the observed lesions. It has previously been suggested that the primary lesion of CMS is located in the endocardium (Ferguson et al. 1990). This assumption was based on the observation that lesions were located in the trabecular tissue of the heart, while the compact musculature, which contains a considerably lower proportion of endocardial tissue, was seldom affected.

Myocardial degeneration is also found in the mild multifocal lesions, probably representing early stages of CMS (Ferguson et al. 1990), which would be in 

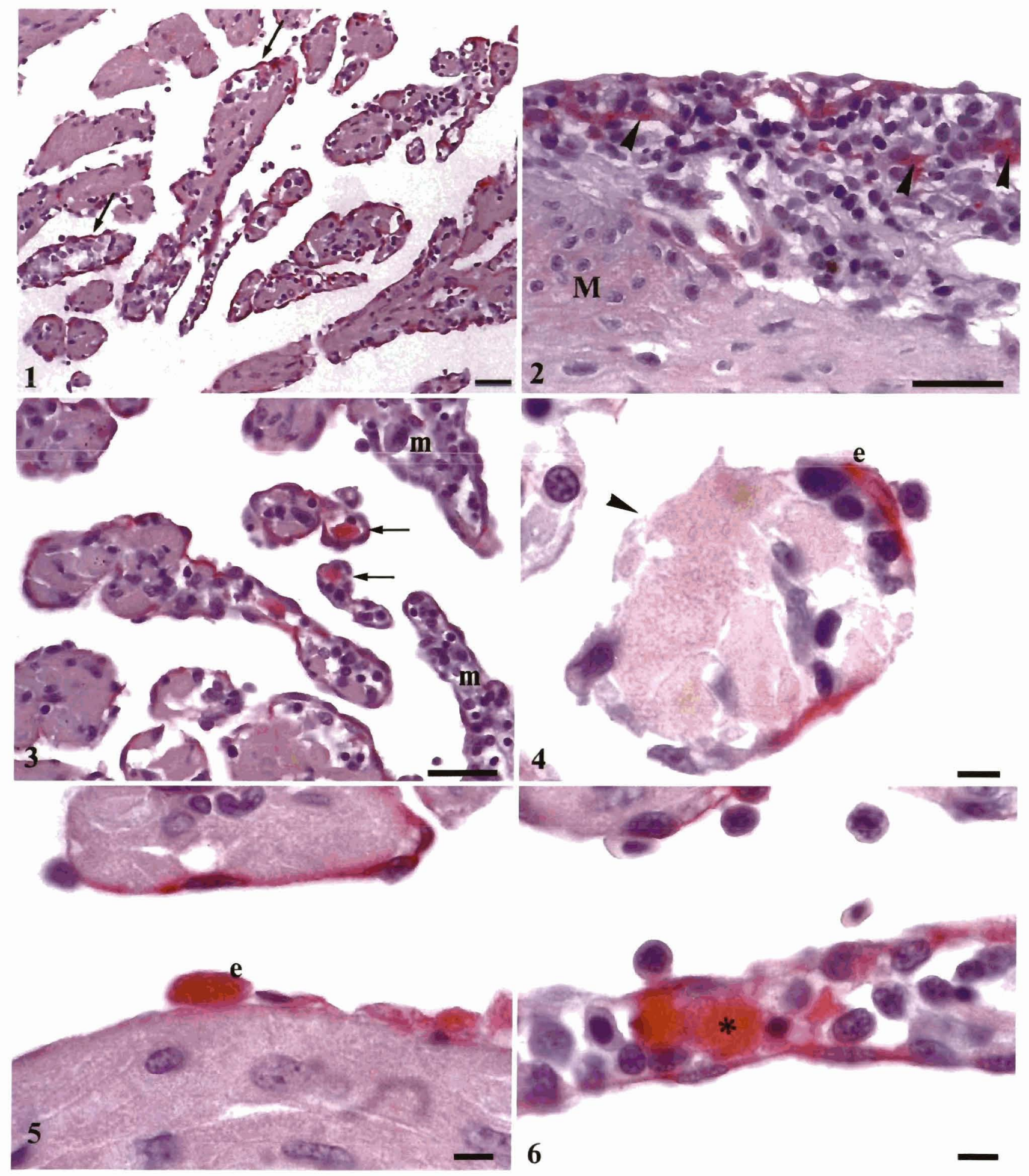

Figs. 1 to 6. Salmo salar. Paraffin sections of the heart. Immunohistochemical staining with anti-SJNNV serum, avidin biotin alkaline phosphatase method, Mayer's haematoxylin counterstain. Fig. 1. Atrium with mild focal lesions of trabecular tissue. Note the distinct immunolabeling (arrows) in the endocardium and the moderate mononuclear cell infiltration. Scale bar $=10 \mu \mathrm{m}$. Fig. 2 . Epicarditis with pronounced mononuclear cell infiltration. Note the presence of cells containing viral antigens (arrowheads). $\overline{\mathrm{M}}$ : compact myocardium. Scale bar $=10 \mu \mathrm{m}$. Fig. 3. Lesions of different severity in trabeculae of the atrium. In some trabeculae with weak immunolabeling, the myocytes have been replaced by mononuclear cells $(\mathrm{m})$. Note the presence of distinct immunolabeling in degenerate myocytes (arrows) and in the endothelium of some trabeculae. Scale bar $=10 \mu \mathrm{m}$. Fig. 4 . Distinct immunolabeled endocardial cell (e) with mononuclear cells both on luminal and mural side. Note that part of the endocardial lining appears to be lacking (arrowhead). Scale bar $=2 \mu \mathrm{m}$. Fig. 5. Trabecula of the atrium with immunolabeled, degenerate endothelial cells (e). Scale bar $=2 \mu \mathrm{m}$. Fig. 6 . Trabeculae with immunolabeled, necrotic myocyte $(*)$ with infiltrated macrophages and lymphocytes. Scale bar $=2 \mu \mathrm{m}$ 


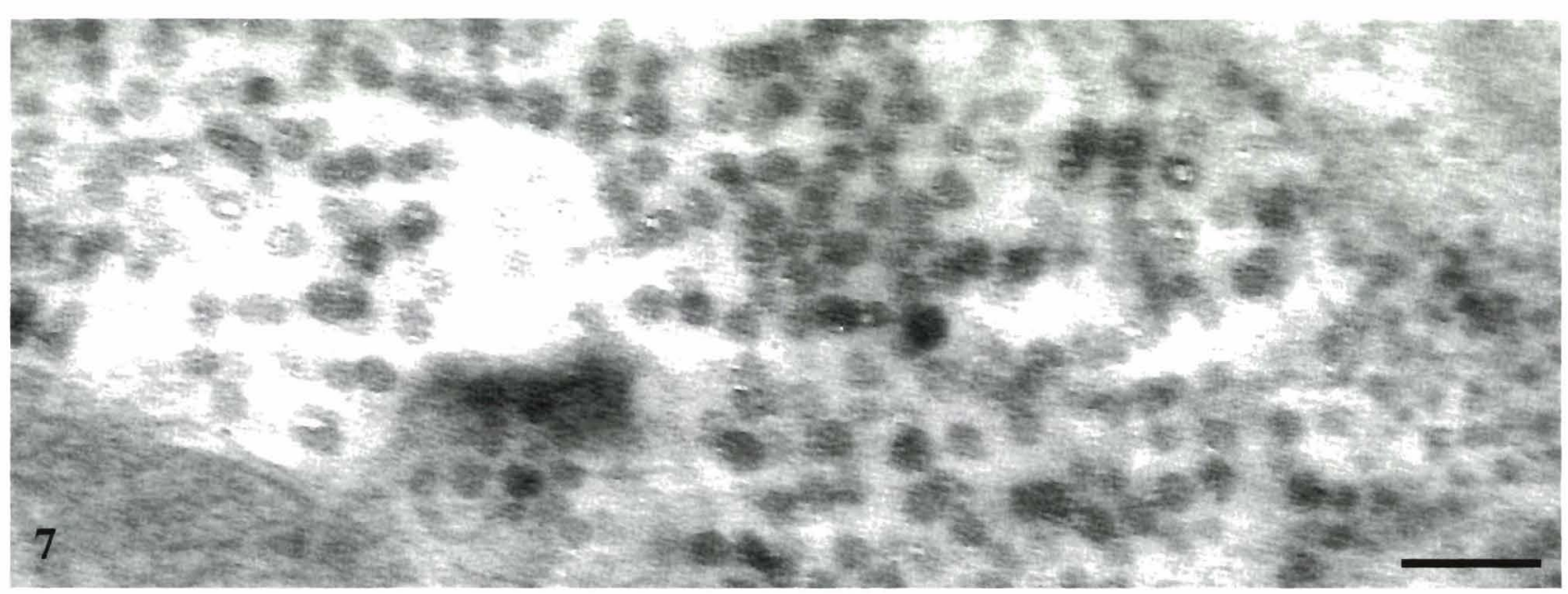

Fig. 7. Salmo salar. High power transmission electron micrograph of virus-like particles in the cytoplasm of a myocyte of the atrium. Scale bar $=100 \mathrm{~nm}$

accordance with immunohisotchemical staining and electron microscopy showing virus antigens/particles in myocytes. In the present study, chronic stages of the disease are recognized by inflammatory changes and sparse presence of viral antigens. Hence, virus seem to be present mainly in endothelial cells but also in some myocytes in the early phase of infection. The cardiac lesions of the Atlantic salmon suffering from CMS are inflammatory and may be described as endomyocarditis and epicarditis, which has previously been proposed by Amin \& Trasti (1988).

The presence of virus in endothelial cells of the heart and/or the vascular bed has been reported from several other viral diseases affecting teleosts, i.e. infectious salmon anemia (Hovland et al. 1994, Falk \& Dannevig 1995), viral haemorrhagic septemia (Wizigmann \& Hoffmann 1982, Meier \& Pfister 1991, Evensen et al. 1994) and infectious haematopoietic necrosis (Carlisle et al. 1979, Drolet et al. 1994). The propensity of the endothelial cells of the endocardium to internalize virions may be related to their high endocytotic activity. It has been demonstrated in smolts of Atlantic salmon that the endothelial cells of the endocardium function as scavengers, clearing the blood of various macromolecules (Smedsrød et al. 1993). High endocytotic function is believed, among other functions, to reflect the number and the variety of receptor molecules on the cell surface, thus increasing the probability of viral internalization. Endotheliotropic virus may be capable of viremia, enabling the virus to spread throughout the body.

In conclusion, our data show that a nodavirus-like agent is associated with the cardiac lesions of CMS and that the endothelial cells may be the primary target cells of the virus in the heart. Infection trials and further studies of the pathogenesis are needed to confirm the etiology of the disease.
Acknowledgements. We thank Dr T. Nakai for providing the anti-SJNNV serum and $\mathrm{Mr} \mathrm{H}$. Ase, AQUA-LAB A/S, for providing tissue samples. Drs $\varnothing$. Evensen and J. Glette are thanked for constructive criticism of the manuscript. We also thank Ingrid Uglenes and Nina Ellingsen for excellent technical assistance.

\section{LITERATURE CITED}

Amin AB, Trasti J (1988) Endomyocarditis in Atlantic salmon in Norwegian seafarms. Bull Eur Assoc Fish Pathol 8: $70-73$

Arimoto M, Mori K, Nakai T, Muroga K, Furusawa I (1993) Pathogenicity of the causative agent of viral nervous necrosis disease in striped jack, Pseudocaranx dentex. J Fish Dis 16:461-469

Arimoto M, Mushiake K, Mizuta Y, Nakai T, Muroga K, Furusawa I (1992) Detection of striped jack nervous necrosis virus (SJNNV) by enzyme-linked immunosorbent assay (ELISA). Fish Pathol 27:191-195

Bloch B, Gravningen K, Larsen JL (1991) Encephalomyelitis among turbot associated with a picornavirus-like agent. Dis Aquat Org 10:65-70

Boonyaratpalin S, Supamattaya K, Kasornchandra J, Hoffmann RW (1996) Picorna-like virus associated with mortality and spongious enephalopathy in grouper Epinephelus malabaricus. Dis Aquat Org 26:75-80

Breuil G, Bonami JF, Pichot Y (1991) Viral infection (picornalike virus) associated with mass mortalities in hatcheryreared sea-bass (Dicentrarchus labrax) larvae and juveniles. Aquaculture 97:109-116

Bruno DW, Poppe T (1996) A colour atlas of salmonid diseases. Academic Press, London

Carlisle JC, Schat A, Elston R (1979) Infectous haematopoetic necrosis in rainbow trout Salmo gairdneri Richardson in a semi-closed system. J Fish Dis 2:511-517

Drolet BS, Rohovec JS, Leong JC (1994) The route of entry and progression of infectious haematopoetic necrosis virus in Oncorhynchus mykiss (Walbaum): a sequential immunohistochemical study. J Fish Dis 17:337-347

Evensen $\varnothing$ (1993) An immunohistochemical study on the cytogenetic origin of pulmonary multinucleate giant cells in porcine dermatosis vegitans. Vet Pathol 31:162-170 
Evensen Ø, Meier W, Wahli T, Olesen NJ, Vestergård Jørgensen PE, Håstein T (1994) Comparison of immunohistochemistry and virus cultivation for detection of viral haemorragic septicaemia virus in experimentally infected rainbow trout Oncorhynchus mykiss. Dis Aquat Org 20: 101-109

Falk K, Dannevig BH (1995) Demonstration of infectious salmon anaemia (ISA) viral antigens in cell cultures and tissue sections. Vet Res 26:499-504

Ferguson HW, Poppe T, Speare D (1990) Cardiomyopathy in farmed Norwegian salmon. Dis Aquat Org 8:225-231

Glazebrook JS, Heasman MP, de Beer SW (1990) Picorna-like viral particles associated with mass mortalities in larval barramundi, Lates calcarifer Bloch. J Fish Dis 13:245-249

Grotmol S, Totland GK, Thorud K, Hjeltnes B (1997) Vacuolating encephalomyelitis, retinitis and endocarditis associated with a nodavirus-like agent: a probable cause of mass mortality of cultured larval and juvenile Atlantic halibut Hippoglossus hippoglossus L. Dis Aquat Org 29:85-97

Hovland T, Nylund A, Watanabe K, Endresen C (1994) Observation of infectious salmon anaemia virus in Atlantic salmon, Salmo salar L. J Fish Dis 17:291-296

Hsu SM, Raine L, Fanger H (1981) Use of an avidin-biotinperoxidase complex $(\mathrm{ABC})$ in immunoperoxidase techniques: a comparison between $\mathrm{ABC}$ and unlabelled antibody (PAP) procedures. J Histochem Cytochem 29: $577-580$

Meier W, Pfister K (1991) Viral hemorrhagic septicemia (VHS) in pike (Esox lucius L.). Clinical, macroscopic, histological and electron-microscopical findings; direct visualization of Egtved virus. Schweiz Arch Tierheilkd 123:37-49

Mori K, Nakai T, Muroga K, Arimoto M, Mushiake K, Furusawa I (1992) Properties of a new virus belonging to Nodaviridae found in larval striped jack (Pseudocaranx dentex) with nervous necrosis. Virology 187:368-371

Mori K, Nakai T, Nagahara M, Muroga K, Mekuchi T, Kanno $T$ (1991) A viral disease in hatchery-reared larvae and juveniles of redspotted grouper. Fish Pathol 26:209-210

Munday BL, Langdon JS, Hyatt A, Humphry JD (1992) Mass mortality associated with a viral-induced vacuolating encephalopathy and retinopathy of larval and juvenile barramundi, Lates calcarifer Bloch. Aquaculture 103: $197-211$

Responsible Subject Editor: J.-A. Leong, Corvallis, Oregon, USA
Munday BL, Nakai T, Nguyen HD (1994) Antigenic relationship of the picornalike virus of larval barramundi, Lates calcarifer Bloch to the nodavirus of larval striped jack, Pseudocaranx dentex (Bloch \& Schneider). Aust Vet J $71: 385$

Muroga K (1995) Viral and bacterial diseases in larval and juvenile marine fish and shellfish: a review. Fish Pathol $30: 71-85$

Nakai T, Nguyen HD, Nishizawa T, Muroga K, Arimoto M, Ootsuki K (1994) Occurrence of viral nervous necrosis in kelp grouper and tiger puffer. Fish Pathol 29:211-212

Nguyen HD, Mekuchi $T$, Imura $K$, Nakai $T$, Nishizawa $T$, Muroga K (1994) Occurrence of viral nervous necrosis (VNN) in hatchery-reared juvenile Japanese flounder Paralichthys olivaceus. Fish Sci 60:551-554

Nguyen HD, Nakai T, Muroga K (1996) Progression of striped jack nervous necrosis virus (SJNNV) infection in naturally and experimentally infected striped jack Pseudocaranx dentex larvae. Dis Aquat Org 24:99-105

Petrusz P (1983) Essential requirements for the validity of immunocytochemical staining procedures. J Histochem Cytochem 31:177-179

Renault T, Haffner PH, Baudin Laurencin F, Breuil G, Bonami JR (1991) Mass mortalities in hatchery-reared sea bass (Lates calcarifer) larvae associated with presence in the brain and retina of virus-like particles. Bull Eur Assoc Fish Pathol 11:68-73

Smedsrød B, Gjøen T, Sveinbjørnsson B, Berg T (1993) Catabolism of circulating collagen in the Atlantic salmon (Salmo salar). J Fish Biol 42:279-291

Totland GK, Hjeltnes BK, Flood PR (1996) Transmission of infectious salmon anaemia (ISA) through natural secretions and excretions from infected smolts of Atlantic salmon Salmo salar during their presymptomatic phase. Dis Aquat Org 26:25-31

Wizigmann G, Hoffmann R (1982) Vergleichende lichtmicroskopische und immunohistologische Untersuchungen bei der viralen hämorrhagischen Septikämie (VHS) der Regenbogenforelle. Zentralbl Veterinärmed (B) 29:782-788

Yoshikoshi K, Inoue K (1990) Viral nervous necrosis in hatchery-reared larvae and juveniles of Japanese parrot-fish, Oplegnathus fasciatus (Temminck \& Schlegel). J Fish Dis 13:69-77

Manuscript first received: October 10, 1996

Revised version accepted: January 14, 1997 